\title{
Relation between genetic diversity and pollution impact in a 1912 experiment with East European Pinus sylvestris provenances
}

\author{
J. OLEKSYN ${ }^{1}$ \\ Polish Academy of Sciences, Institute of Dendrology, Parkowa 5, PL-62-035 Kórnik, Poland \\ and \\ University of Minnesota, Department of Forest Resources, 1530 N. Cleveland Avenue, St. Paul, MN 55108, U.S.A. \\ W. Prus-GLOWACKI \\ Adam Mickiewicz University, Department of Genetics, Dabrowskiego 165, PL-60-594 Poznan, Poland \\ M. GIERTYCH \\ Polish Academy of Sciences, Institute of Dendrology, Parkowa 5, PL-62-035 Pórnik, Poland \\ AND \\ P.B. REICH \\ University of Minnesota, Department of Forest Resources, 1530 N. Cleveland Avenue, St. Paul, MN 55108, U.S.A.
}

Received February 7, 1994

Accepted August 2, 1994

Oleksyn, J., Prus-Glowacki, W., Giertych, M., and Reich, P.B. 1994. Relation between genetic diversity and pollution impact in a 1912 experiment with East European Pinus sylvestris provenances. Can. J. For. Res. 24: $2390-2394$.

Results are presented of genetic variation and growth decline due to pollution for 11 European populations, 1 Turkish population, and 1 Siberian population of Scots pine (Pinus sylvestris L.) growing in a provenance experiment established in 1912 in Pulawy, southeastern Poland. Since 1966 this area has been subjected to acute pollution from a nitrogen-fertilizer factory emitting high levels of $\mathrm{SO}_{2}, \mathrm{NO}_{x}, \mathrm{NH}_{3}$, and other toxic compounds. A significant negative correlation was found between genotype polymorphism indices and radial growth decline since 1966 assessed using tree-ring analysis $(r=-0.58, P=0.04)$. Populations with the highest values for genotype polymorphism index, numbers of alleles per locus, and numbers of genotypes per locus exhibited less of a decline in radial growth than those populations with lower values for these parameters. The results provide experimental support for the hypothesis that genetically richer populations are better adapted to changing conditions and suggest that such populations are less sensitive to air pollution in terms of growth reduction.

Oleksyn, J., Prus-Glowacki, W., Giertych, M., et Reich, P.B. 1994. Relation between genetic diversity and pollution impact in a 1912 experiment with East European Pinus sylvestris provenances. Can. J. For. Res. $24: 2390-2394$.

La variabilité génétique ainsi que la diminution de croissance imputable à la pollution ont été étudiées chez 11 provenances européennes de Pinus sylvestris, 1 provenance de Turquie et 1 de Sibérie rassemblées en essai de provenances établi en 1912 à Puławy, dans le sud-est de la Pologne. Depuis 1966, cette région a été l'objet d'impacts importants résultant de la pollution par une usine de fertilisants azotés qui émet de forts niveaux de $\mathrm{SO}_{2}, \mathrm{NO}_{x}, \mathrm{NH}_{3}$ et autres composés toxiques. À l'aide de l'analyse des cernes annuelles, une corrélation négative et significative a été observée entre les indices de polymorphisme génotypique et la diminution de croissance radiale depuis $1966(r=-0,58$, $P=0,04)$. Les populations affichant les valeurs les plus élevées d'indice de polymorphisme génotypique, de nombres d'allèles par locus et de nombres de génotypes par locus démontraient moins de diminution de croissance radiale que les populations affichant de plus faibles valeurs pour ces paramètres. Ces résultats permettent de supporter expérimentalement l'hypothèse voulant que les populations génétiquement plus riches s'adaptent mieux à des conditions environnementales changeantes. Ces résultats suggèrent que ces populations sont moins sensibles à la pollution de l'air en termes de réduction résultante de croissance.

[Traduit par la Rédaction]

\section{Introduction}

Isoenzymes are frequently used for studies on differentiation of tree populations within their natural ranges. Less numerous are studies in which genetic structure was linked with susceptibility to biotic or abiotic factors. In general, there are expectations that more heterozygous populations will exhibit higher resistance to various stress factors. Gregorius et al. (1985) claims that "high levels of genetic multiplicity or diversity and of heterozygosity are necessary prerequisites for the preservation of the adaptability of forest tree populations and hence for the stability of the ecosystems which they support." However, in many studies the genetic

\footnotetext{
${ }^{1}$ Author to whom all correspondence should be addressed.

structure of populations was found to be unrelated to such factors. For example, Liu et al. (1990) found that Taxodium distichum (L.) Richard mortality resulting from a discharge of hot water from nuclear production reactors was not genotype selective and allele frequencies were heterogeneous over space. Also, laboratory studies with Norway spruce (Picea abies (L.) Karst.) seedlings grown in the presence of high $\mathrm{Al}$ levels showed high individual variation in $\mathrm{Al}$ sensitivity and a lack of correlation between the genic multiplicity of the maternal genotype and the $\mathrm{Al}$ sensitivity of its progeny (Geburek et al. 1986).

There are numerous indications that the effects of environmental stress is genetically selective (Mejnartowicz 1983; Gregorius et al. 1985; Bergmann and Scholz 1984, 1987). 
A comparison between healthy and air-pollution-damaged trees conducted in high-elevation Norway spruce stands in the Alps showed that certain heterozygous genotypes were more frequent among the healthy trees (Reutz and Bergmann 1989). Also, Hattemer and Müller-Starck (1989) found that in a polluted environment, increasing genetic variation favors viability in individual trees and in populations. They found that under certain stress conditions, losses in genetic variation are inevitable. Prus-Glowacki and Godzik (1991) reported that Scots pine (Pinus sylvestris L.) seedlings grown in a polluted area demonstrated a significant decrease in both heterozygosity and degree of genetic polymorphism (by $30 \%$ and $20 \%$, respectively) compared with the control. Genetic inventories made in six old Fagus sylvatica L. stands exposed for a long time to air pollution stress revealed losses of genetic variation and confirmed the importance of a high degree of heterozygosity and genetic diversity for the survival of plants (Müller-Starck and Hattemer 1989). For Picea rubens Sarg. in eastern North America, it was suggested that very low genetic variation in combination with environmental stress may be responsible for the species' widespread decline (DeHayes and Hawley 1988).

The purpose of this study was to examine the relations between genetic variation and growth decline induced by pollution from a point source emitter that started operation in 1966 in 13 diverse Scots pine populations spanning the Eastern European range of the species.

\section{Materials and methods}

\section{Description of the experimental area and plant material}

The experimental area was established with various provenances of pine in 1912-1914 by S.Z. Kurdiani in compartment 25 of the present Forest Range Ruda, Institute of Cultivation and Fertilization (IUNG), Pulawy, Poland. Seeds of Scots pine came from 13 locations originating from diverse regions in Eastern Europe and Siberia (Table 1). Originally 4600 trees/ha were planted for all provenances. The plots were $35 \times 40 \mathrm{~m}$ in size and unreplicated. The site was managed by typical silviculture for 69 years $(1912-1981)$ before it was designated to be an experiment. Detailed information about this experiment, its description, 'scientific purpose, as well as dendrometric and viability data are described by Oleksyn and Giertych (1984) and Oleksyn (1987). The mean annual precipitation for the years 1920-1987 for the region was $570 \mathrm{~mm}$, and the mean monthly temperatures over the same period ranged from $-3.8^{\circ} \mathrm{C}$ in January to $18.5^{\circ} \mathrm{C}$ in July. The experimental area is situated at $51^{\circ} 37^{\prime} \mathrm{N}$, $22^{\circ} 06^{\prime} \mathrm{E}, 140 \mathrm{~m}$ elevation, on a slightly southeast-facing slope. The soils are sandy and composed of shallow sands and gravels. Phytosociologically the area is a Pineto-Quercetum association (Matuszkiewicz and Matuszkiewicz 1956).

\section{Pollution source}

The nitrogen-fertilizer factory in Pulawy, Poland, is located $3 \mathrm{~km}$ northwest from the experimental area. This area had no significant level of air pollution until 1966, when the factory started operation. The first symptoms of tree and shrub injuries thought to result from pollutants were observed in early spring of 1967 (Jakubczak et al. 1968). They were most apparent in the region next to a settling pond for industrial sewage and in the area subjected to ashfall from the heat- and power-generating plants. In the same year, many Scots pine trees died within an area of about 85 ha. Since that time the destruction zone has expanded several fold, reaching an area of about 1200 ha in 1978 (Puszkar 1980, as cited in Trojanowski 1983). It extends primarily to the east and north, directions associated with the prevailing winds of the region.
The zone of injury to plants was also associated to a large extent with the height of the emitting chimneys. In the case of toxic nitrogen compounds, the emissions occurred from relatively low emitters: 6 chimneys $47 \mathrm{~m}$ tall emitted ammonia nitrate and 5 chimneys $30 \mathrm{~m}$ tall emitted gaseous ammonia (Trojanowski 1983). Some of the nitrogen compounds reached the atmosphere from the surface of tanks with industrial sewage. This resulted in the formation of particularly high concentrations of different pollutants near the factory itself. According to Adamczyk-Winiarska (1980), within a radius of $2.5 \mathrm{~km}$ from the emitter, the $\mathrm{NH}_{3}$ concentrations in the air have exceeded the permissible norm for Poland by as much as $30 \%$. In the case of $\mathrm{NO}_{x}$, the concentrations have exceeded the norm by $10 \%$ at the distance of $1 \mathrm{~km}$ from the factory.

Sulfur dioxide was emitted from a chimney $160 \mathrm{~m}$ tall. This reduced $\mathrm{SO}_{2}$ levels near the nitrogen-fertilizer factory itself, but transported the pollutants over distances as far as $120 \mathrm{~km}$. A reduction in pollutant emission was observed beginning in the 1970s resulting from a decrease in production (Kępka 1986). More detailed data on the extent and type of air pollution is given in Oleksyn et al. (1993).

\section{Tree-ring analysis}

From each provenance 13 to 29 trees were sampled for tree-ring analyses. All cores were dried, mounted, and sanded using a standard procedure (Fritts 1976). The ring-width sequences of all trees were cross-dated through the skeleton plot method (Stokes and Smiley 1968). All provenances of Scots pine exhibit some absent or missing rings in the period of 1966-1988. Detailed information on sampling and dating is presented elsewhere (Oleksyn et al. 1993).

The sampled cores were dated and the ring widths were measured to the nearest $0.01 \mathrm{~mm}$ using a computerized measuring machine described by Robinson and Evans (1980). An accuracy check of the dating was done using a computer-assisted method, program COFECHA (Holmes et al. 1986). When the program is applied to dated ring-width measurements, it identifies all locations within series that may have weak or erroneous cross-dating or measurement errors. All cores and measurements with potential errors were then re-examined to evaluate possible weaknesses, and corrections were made when necessary. An additional run of COFECHA verified that all changes were correct and that the measurements were ready for chronology assembly.

Finally, because all trees were the same age, the ring widths from cores of the same provenances could be combined into a series of average values for each year. The average ring-width series of each variant was then converted to standardized indices using the computer program INDEX (Graybill 1979). The process of standardization removes the trends in growth associated with increasing tree age, a major source of nonstationarity in the time series. The transformation produces a homogeneous time series with a mean of one. In this study a negative exponential curve [1] $Y_{t}=a \mathrm{e}^{-b t}+k$

was fit to each averaged ring-width series beginning with the earliest ring and ending in 1965, the last year of the prepollution period. The values of $a, b$, and $k$ vary from series to series depending upon the shape of the curve required to fit the data; $\mathrm{e}$ is the base of natural logarithms and $Y_{t}$ is the expected growth at the given year $t$, where $t$ varies from 1 to the total number of rings $(n)$ in the prepollution period.

The equation developed on only the prepollution period was applied from year $n+1$ to $n+p$ to extend the curve to the last year sampled in the pollution period ( $p=23$ from 1966 to 1988 ).

Ring-width indices for each provenance were obtained by

[2] $I_{t}=\frac{R_{t}}{Y_{t}}$

where $R_{t}$ is the average ring width for the year $t, Y_{t}$ is the predicted 
TABLE 1. Mean number of alleles $(n)$ and genotypes $(G)$ per locus, genotype polymorphism index $\left(P_{\mathrm{g}}\right)$, and pollution-induced growth decline $(\Delta Y)$ of Scots pine provenances growing in an area subjected since 1966 to pollution from a nitrogen-fertilizing factory in Pulawy, Poland

\begin{tabular}{lccccccr}
\hline \hline & $\begin{array}{c}\text { Lat. } \\
\text { Provenance* }\end{array}$ & $\begin{array}{c}\text { Long. } \\
(\mathrm{N})\end{array}$ & $\begin{array}{c}\text { No. of trees } \\
\text { sampled }\end{array}$ & $n^{\dagger}$ & $G^{\dagger}$ & $P_{\mathrm{g}}^{\dagger}$ & $\begin{array}{r}\Delta Y^{\ddagger} \\
(\%)\end{array}$ \\
\hline Kars & $40^{\circ} 30^{\prime}$ & $42^{\circ} 00^{\prime}$ & 14 & 2.37 & 2.87 & 0.459 & 59.2 \\
Arkhangelsk & $63^{\circ} 50^{\prime}$ & $45^{\circ} 10^{\prime}$ & 25 & 2.75 & 3.75 & 0.498 & 59.7 \\
Kharkov & $50^{\circ} 00^{\prime}$ & $36^{\circ} 20^{\prime}$ & 27 & 2.75 & 3.75 & 0.529 & 6.2 \\
Olonets & $61^{\circ} 30^{\prime}$ & $39^{\circ} 00^{\prime}$ & 27 & 2.25 & 3.00 & 0.440 & 52.3 \\
Voronezh & $51^{\circ} 06^{\prime}$ & $40^{\circ} 17^{\prime}$ & 25 & 2.37 & 3.37 & 0.460 & 26.3 \\
Vologda & $59^{\circ} 43^{\prime}$ & $36^{\circ} 52^{\prime}$ & 16 & 2.87 & 3.62 & 0.490 & 42.3 \\
Jenisejsk & $58^{\circ} 00^{\prime}$ & $62^{\circ} 00^{\prime}$ & 15 & 2.37 & 3.50 & 0.458 & 25.9 \\
Novgorod & $59^{\circ} 37^{\prime}$ & $33^{\circ} 33^{\prime}$ & 12 & 2.37 & 2.87 & 0.423 & 51.2 \\
Volyniya & $50^{\circ} 45^{\prime}$ & $25^{\circ} 18^{\prime}$ & 30 & 3.00 & 3.75 & 0.518 & 14.7 \\
Ufa & $55^{\circ} 00^{\prime}$ & $52^{\circ} 00^{\prime}$ & 12 & 2.37 & 2.62 & 0.449 & 12.6 \\
Kiev & $50^{\circ} 50^{\prime}$ & $30^{\circ} 17^{\prime}$ & 30 & 2.62 & 3.37 & 0.501 & 35.4 \\
Tver & $58^{\circ} 38^{\prime}$ & $37^{\circ} 13^{\prime}$ & 17 & 2.62 & 3.12 & 0.478 & 45.9 \\
Kurland & $56^{\circ} 07^{\prime}$ & $21^{\circ} 08^{\prime}$ & 30 & 3.12 & 3.75 & 0.543 & 15.7 \\
\multicolumn{1}{c}{ Avg. } & & & & & & & \\
\hline
\end{tabular}

*See Oleksyn and Giertych (1984) for plan and description.

Prus-Glowacki and Bernard (1994).

${ }^{\ddagger}$ See text and Oleksyn et al. (1993) for detailed information.

average ring width for the same year, and $t$ varies from 1 to $n+$ $p$ through both the prepollution and pollution periods.

The percentage of growth changes $(\Delta Y)$ for the individual years during the air pollution period was calculated from the equation:

[3] $\Delta Y=\frac{R_{t}-Y_{t}}{Y_{t}} \times 100$

Independent calculations, where the growth and climatic variations in the chronologies were calibrated using indices of the prepollution chronologies and climatic data for the corresponding period, were very similar to those presented in Table 1 (Oleksyn et al. 1993). An abrupt growth decline was observed after 1966 in all pine populations.

\section{Isoenzyme analyses}

Dormant winter buds were used for isoenzymatic analyses. Plant material was collected from 12 to 30 randomly chosen trees from each provenance (Table 1). When less than 30 individuals were available, the samples from all living trees were collected. Statistical tests were performed to establish the effect of sample size on the genetic parameters calculated. Modeling number of genes per locus $(n)$ on the sample size and overall mean frequencies of all alleles (30) in eight loci revealed that the samples split into two groups: with $n=2.75$ (22 alleles per 8 loci) for populations with less than 18 trees per sample and $n=2.88$ (23 alleles per 8 loci) for populations with more than 24 trees per sample. The groups did not differ significantly in the actual number of alleles per locus $(P=0.21)$; however, there were differences in genotypes per locus $(G)$ and genotype polymorphism index $\left(P_{\mathrm{g}}\right)$ for the two groups. Thus, all relationships of genetic parameters with survival would be potentially confounded by sample size. Further investigation was made separately for the two groups of populations of the relationships of genetic parameters with growth decline. In this case the sample size did not affect the result. The correlation coefficients were even improved when made only for populations with 25 or more trees per sample, thus the conclusions for the whole material were unaffected by sample size. A partial correlation analysis has shown that when the effect of sample size was taken out, the relation between growth decline and genetic parameters was still substantial. A similar analysis for survival and standing volume showed that sample size significantly confounded the relations with genetic parameters and therefore they are not reported here.

Variation in the following enzymatic loci was studied: fluorescent esterase, FEST (EC 3.1.1.1); glutamic-oxaloacetic transaminase, GOT, two loci (EC 2.6.1.1); diaforase, DIA (EC 1.8.1.4); glutamate dehydrogenase, $G D H$ (EC 1.4.1.3); alcohol dehydrogenase, $A D H$ (EC 1.1.1.1); shikimate 5-dehydrogenase, $S h D H$ (EC 1.1.1.25); and NADH-dependent dehydrogenase, $N D H$. The separation of isoenzymes on starch gels and the genetic interpretation of the results were performed as described by Muona and Szmidt (1985) and Prus-Glowacki (1986). The following genetic parameters were calculated for each population: mean number of alleles $(n)$ and genotypes per locus $(G)$, effective numbers of alleles $\left(n_{\mathrm{e}}\right)$, heterozygosity observed $\left(H_{\mathrm{o}}\right)$ and expected $\left(H_{\mathrm{e}}\right)$, fixation index $(F)$, and genotype polymorphism index $\left(P_{\mathrm{g}}\right)$.

Several additional genetic parameters such as the frequency of alleles and genotypes, total heterozygosity, genetic differentiation of populations, and genetic similarity coefficients were calculated and discussed in a separate paper (Prus-Głowacki and Bernard 1994).

\section{Results}

Data on gene diversity and pollution-induced growth decline of Scots pine provenances are presented in Table 1. Of the studied genetic parameters, the number of alleles per locus, the number of genotypes per locus, and the genotype polymorphism index were the parameters related to pollutioninduced growth decline (Fig. 1) (measured as percent of radial growth decline). Genetic parameters such as frequency of alleles and genotypes, total heterozygosity, genetic differentiation of populations, and genetic similarity coefficients were unrelated to growth decline.

For growth decline a significant negative correlation was found with the genotype polymorphism index $(r=-0.58$, $P=0.04)$. Number of alleles and genotypes per locus were marginally related to the decline in radial increment (Fig. 1). In general, populations with higher values of $P_{\mathrm{g}}, G$, and $n$ exhibited a smaller decline in radial growth than populations with lower values of these parameters. The highest values of $P_{\mathrm{g}}, 0.543,0.529$, and 0.518 , were noted for the 

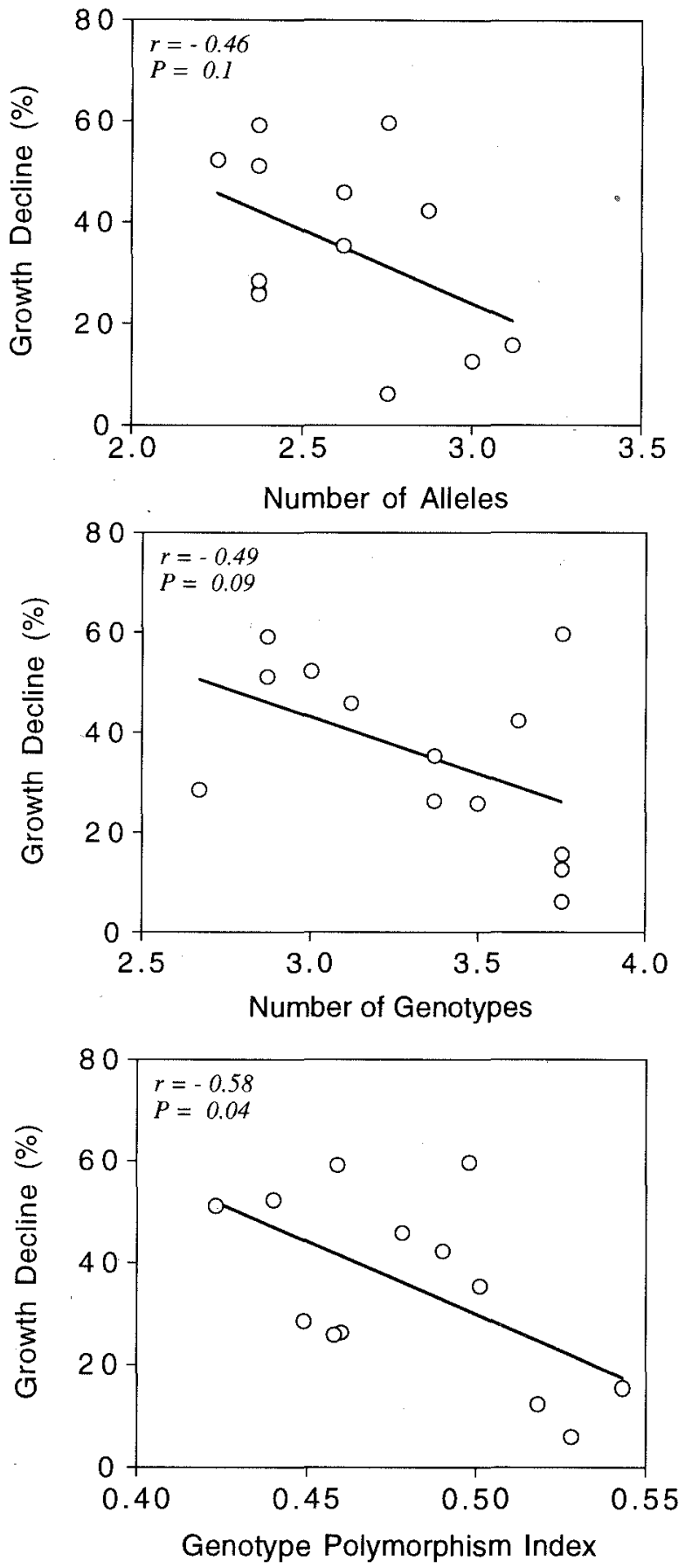

FIG. 1. Number of alleles per locus, number of genotypes per locus, and genotype polymorphism index in relation to pollutioninduced growth decline of Scots pine provenances growing in an area subjected since 1966 to pollution from a nitrogen-fertilizer factory in Pulawy, Poland.

populations Kurland, Kharkov, and Volyniya, respectively. The same populations were among those with the lowest values of growth decline (Table 1 and Fig. 1).

Genetic diversity was largely unrelated to geographic origin. Only two populations, Novgorod and Olonets, which are from geographically close and climatically comparable areas, were genetically similar. Those two populations also exhibited an almost identical decline in radial growth (Table 1).

\section{Discussion}

Significant relations 'between several genetic indices and pollution-induced growth decline provide experimental support to Lerner's (1954) hypothesis that genetically richer populations are tetter adapted to changing conditions (Fig. 1). This study provided also circumstantial evidence that such populations could also be less sensitive to pollution in terms of growth reduction.

The most polymorphic population, from Kurland (Table 1), exhibited the highest survival and was among the most productive provenances in the Puławy experiment (Giertych 1979; Giertych and Oleksyn 1981,1991; Oleksyn and Giertych 1984). It represents a well-known and widely cultivated (in Europe and North America) race known as "Riga Pine." Trees from the same region were less affected in various polluted environments and in laboratory fumigations (Oleksyn and Białobok 1986; Oleksyn 1988; Oleksyn et al. 1988) and were highly polymorphic in studies on allozyme differentiation among European Scots pine populations (PrusGlowacki et al. 1993). This supports the idea of linkages between productivity, stress resistance, and genetic richness of Scots pine populations.

Our results are in good agreement with those of Geburek et al. (1987), who found that air-pollution-tolerant openpollinated families of Scots pine had 2.5 times greater genic and genotypic multilocus diversities than the sensitive group of trees.

The data presented in this study suggest that ability to maintain a viable population in a polluted environment may be related to genetic richness.

\section{Acknowledgement}

This study was possible by support from the National Geographic Society (4435-90).

Adamczyk-Winiarska, Z. 1980. Effect of pollution emitted by Nitrogen Works in Pulawy on chemical property of soils. [In Polish.] Publ. Instytut Uprawy Nawożenia i Gleboznawstwa, Puławy, Poland. R154.

Bergmann, F., and Scholz, F. 1984. Effects of selection pressure by $\mathrm{SO}_{2}$ pollution on genetic structures of Norway spruce (Picea abies). In Population genetics in forestry. Lect. Notes Biomath. 60: 267-275.

Bergmann, F., and Scholz, F. 1987. The impact of air pollution on the genetic structure of Norway spruce. Silvae Genet. 36: $80-83$.

DeHayes, D.H., and Hawley, G.J. 1988. Genetic uniformity: a factor in red spruce decline? Diversity, 16: 22-23.

Fritts, H.C. 1976. Tree-rings and climate. Academic Press, London, New York, San Francisco.

Geburek, T., Scholz, F., and Bergmann, F. 1986. Variation in aluminium-sensitivity among Picea abies (L.) Karst. seedlings and genetic differences between their mother trees as studied by isozyme-gene-markers. Angew. Bot. 60: 451-460.

Geburek, T., Scholz, F., Knabe, W., and Vornweg, A. 1987. Genetic studies by isozyme gene loci on tolerance and sensitivity in an air polluted Pinus sylvestris field trail. Silvae Genet. 36: 49-53.

Giertych, M. 1979. Summary of results on Scots pine (Pinus sylvestris L.) height growth in IUFRO provenance experiments. Silvae Genet. 28: 136-152.

Giertych, M., and Oleksyn, J. 1981. Summary of results on Scots pine (Pinus sylvestris L.) volume production in Ogievskij's pre-revolutionary Russian provenance experiments. Silvae Genet. 30: 56-74.

Giertych, M., and Oleksyn, J. 1991. Studies on genetic variation 
in Scots pine (Pinus sylvestris L.) coordinated by IUFRO. Silvae Genet. 41: 133-143.

Graybill, D.A. 1979. Revised computer program for tree-ring research. Tree-Ring Bull. 39: 77-82.

Gregorius, H.-R., Hattemer, H.H., Bergmann, F., and MüllerStarck, G. 1985. Umweltbelastung und Anpassungsfähigkeit von Baumpopulationen. Silvae Genet. 34: 230-241.

Hattemer, H.H., and Müller-Starck, G. 1989. Forest decline as an adaptational process. Allg. Forst- Jagdzg. 160: 222-229.

Holmes, L.R., Adams, R.K., and Fritts, H.C. 1986. Tree-ring chronologies of western North America: California, Eastern Oregon and Northern Great Basin with procedures used in the chronology development work including users manuals for computer programs COFECHA and ARSTAN. Laboratory of Tree-Ring Research, University of Arizona, Tucson. Chronol. Ser. 6.

Jakubczak, Z., Koter, T., and Siuta, J. 1968. Effect of industrial emissions on forest plants in the Pulawy region. [In Polish.] Postepy Nauk Roln. 5(113): 75-87.

Kępka, J. 1986. Predicting from oracles. [In Polish.] Przegl. Techniczny, 36(1986): 8-9.

Lerner, I.M. 1954. Genetic homeostasis. Oliver and Bayd, Edinburgh.

Liu, E.H., Iglich, E.M., Sharitz, R.R., and Smith, M.H. 1990. Population genetic structure of bladcypress (Taxodium distichum) in a thermally affected swamp forest. Silvae Genet. 39: 129-133.

Matuszkiewicz, M., and Matuszkiewicz, A. 1956. Pflanzensoziologische Untersuchungen im Forstrevier "Ruda" bei Pulawy (Polen). Acta Soc. Bot. Pol. 25: 329-400.

Mejnartowicz, L. 1983. Changes in genetic structure of Scots pine (Pinus sylvestris L.) population affected by industrial emission of fluoride and sulphur dioxide. Genet. Pol. 24: 41-50.

Müller-Starck, G., and Hattemer, H.H. 1989. Genetic effects of environmental stress on old stands and young growth of beech (Fagus sylvatica). Forstarchiv, 60: 17-22.

Muona, O., and Szmidt, A. 1985. A multilocus study of natural populations of Pinus sylvestris. In Population genetics in forestry. Lect. Notes Biomath. 60: 226-240.

Oleksyn, J. 1987. Air pollution effects on 15 European and Siberian Scots pine (Pinus sylvestris L.) provenances growing in a 75-year-old experiment. Arbor. Kornickie, 32: 151-162.

Oleksyn, J. 1988. Height growth of different European Scots pine Pinus sylvestris L. provenances in a heavily polluted and a control environment. Environ. Pollut. 55: 289-299.

Oleksyn, J., and Białobok, S. 1986. Net photosynthesis, dark respiration and susceptibility to air pollution of 20 European provenances of Scots pine Pinus sylvestris L. Environ. Pollut. Ser. A Ecol. Biol. 40: 287-302.

Oleksyn, J., and Giertych, M. 1984. Results of a 70-year-old provenance experiment with Scots pine (Pinus sylvestris L.) in Puławy, Poland. Silvae Genet. 33: $22-27$.

Oleksyn, J., Karolewski, P., and Rachwal, L. 1988. Susceptibility of European Pinus sylvestris $\mathrm{L}$. populations to $\mathrm{SO}_{2}, \mathrm{NO}_{2}$, $\mathrm{SO}_{2}+\mathrm{NO}_{2}$ and $\mathrm{HF}$ under laboratory and field conditions. Acta Soc. Bot. Pol. 57: 107-115.

Oleksyn, J., Fritts, H.C., and Hughes, M.K. 1993. Tree-ring: analysis of different Pinus sylvestris provenances, Quercus robur, Larix decidua and $L$. decidua $\times$ L. kaempferi affected by air pollution. Arbor. Kornickie, 38: 87-111.

Prus-Glowacki, W. 1986. Demographic processes in population of Pinus sylvestris from industrial polluted area. In Proceedings, Genpool of Forest Woody Species, Its Conservation and Utilization, Nitra, Czechoslovakia. Edited by A. Kormutek and D. Uzak. pp. 107-122.

Prus-Glowacki, W., and Bernard, E. 1994. Allozyme variation in populations of Pinus sylvestris L. from a 1912 provenance trial in Pulawy (Poland). Silvae Genet. 43: 132-138.

Prus-Głowacki, W., and Godzik, S. 1991. Changes induced by zinc smelter pollution in the genetic structure of pine (Pinus sylvestris L) seedling populations. Silvae Genet. 40: 184-188.

Prus-Głowacki, W., Urbaniak, L., and Zubrowska-Gil, M. 1993. Allozyme differentiation in Mid-European and Scandinavian populations of Scots pine (Pinus sylvestris L.). Genet. Pol. 34: $159-176$.

Puszkar, T. 1980. Changes in certain zoocenose elements in agricultural systems exposed to acute levels of industrial pollutants. [In. Polish.] Publ. Instytut Uprawy Nawożenia i Gleboznawstwa, Pulawy, Poland. R157.

Reutz, W.F., and Bergmann, F. 1989. Possibilities of identifying autochthonous high-altitude stands of Norway spruce (Picea abies) in the Berchtesgaden Alps. Forstwiss. Centralbl. 108: $164-174$.

Robinson, W., and Evans, R. 1980. A microcomputer-based treering measuring system. Tree-Ring Bull. 40: 59-63.

Stokes, M.A., and Smiley, T.L. 1968. An introduction to treering dating. University of Chicago Press, Chicago.

Trojanowski, H. 1983. The changes in natural environment of the forest "Ruda" under the influence of emissions of Zakłady Azotowe (Nitrogen Factory) with particular attention to Carabidae. [In Polish.] Pr. Nauk. Inst. Ochr. Rosl. Warsz. 25(2): 5-93. 